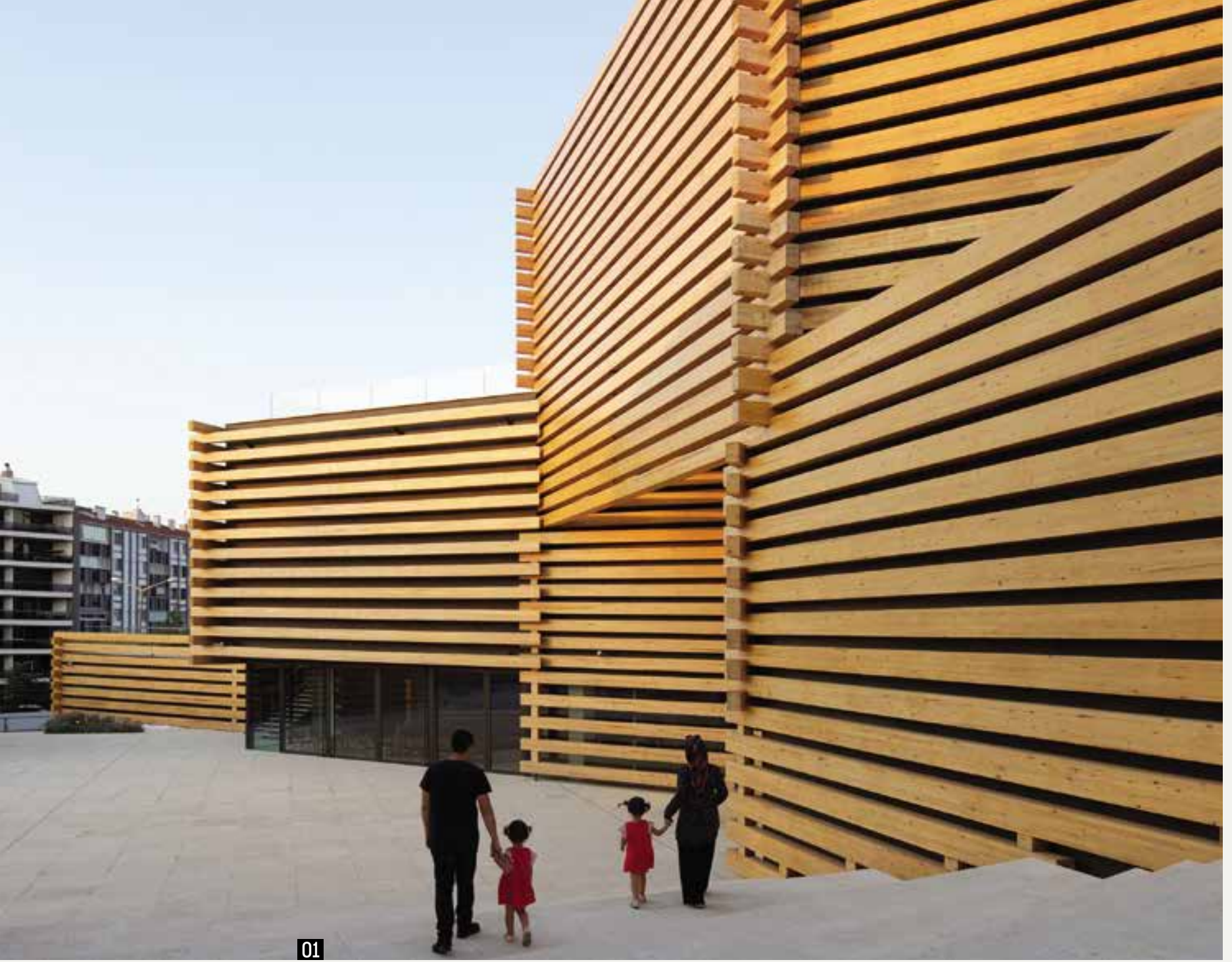

\title{
A HAGYOMÁNY EGYENSÚLYA
}

ÉPÍTÉSZ |

Kengo Kuma

ODUNPAZARI MÚZEUM | TÖRÖKORSZÁG

_ Kevés épület ragadja meg a hely adottságait és történelmi hagyományait a kortárs és modern építészet olyan különleges egyensúlyával, mint Kengo Kuma Odunpazari Modern Múzeuma (OMM) Törökországban. A sajátos karakter a japán mester különleges stílusából ered: az OMM múzeum egyszerre hagyományos és provokatív, modern és illeszkedó, kortárs és történelmi.
_Kengo Kuma múzeumépületei egy sajátos fejlődési ívbe illenek: a Bato Hirosige Múzeum és a Kőmúzeum nemcsak jelentős alkotásai, hanem korai munkái is: mindkettő kereken 20 éve, 2000-ben épült. A két épület Kengo Kuma későbbi építészetét is alapjaiban meghatározza. Mindkét épület a helyi hagyományokból táplálkozik. A Hirosige Múzeum a vidékre jellemző faépítészetből, [I] a Kőmúzeum [2] pedig a tájra jellemző kövekkel és szerkezetekkel dolgozott (bár kevéssé ismert, de a kőépítészetnek is vannak vernakuláris hagyományai Japánban). Mindkét épület egy tudatos 


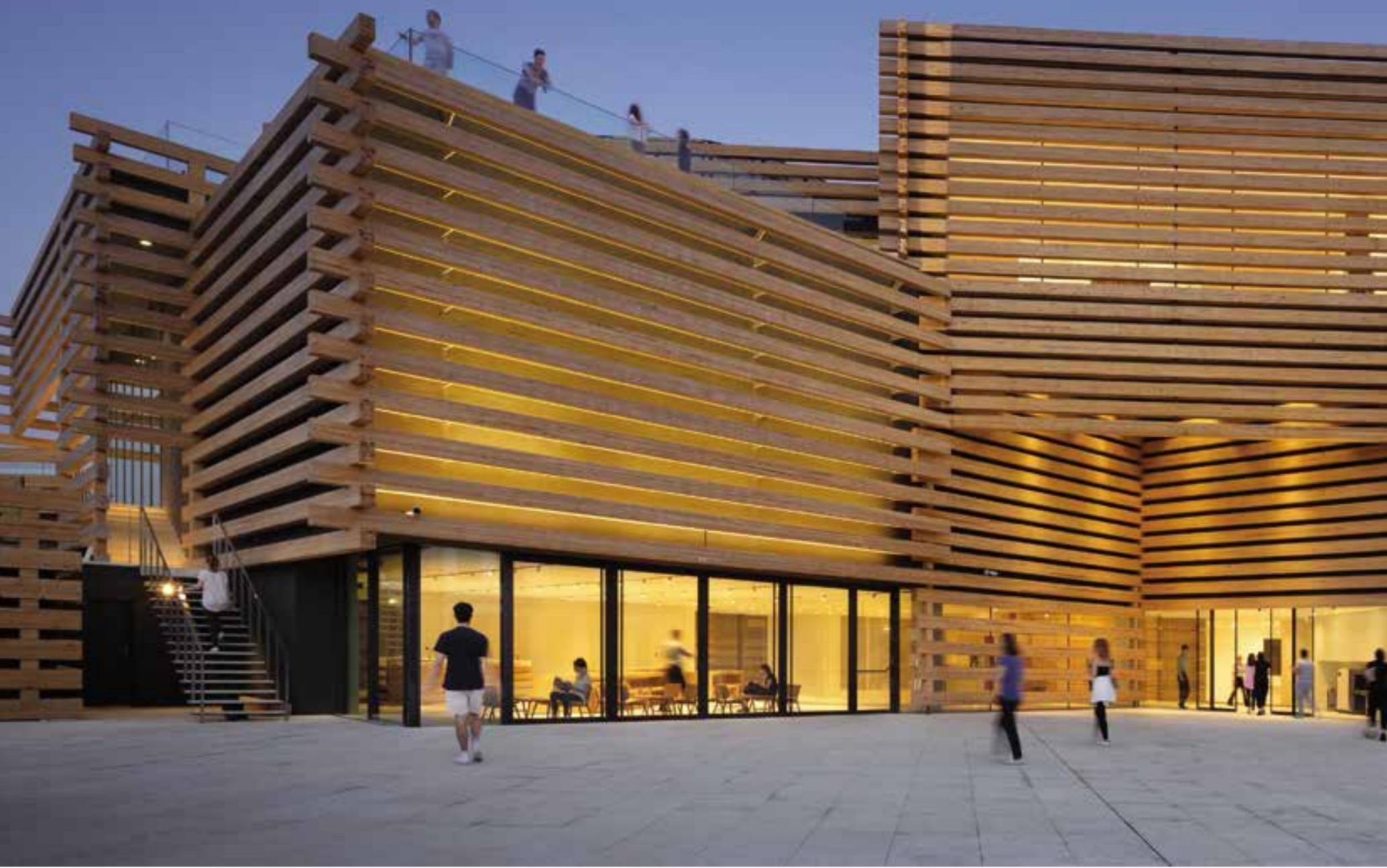

múzeumépületeit is meghatározzák: Kínában helyi kerámiákból és cserepekből épít különleges és egyedi árnyékolót a Kínai Népművészeti Akadémia múzeumépületéhez, és sajátos kő-beton homlokzatot tervez a Victoria $\delta$ Albert Múzeumhoz Skóciában. Nincs ez másképpen az OMM múzeum esetében sem, ahol az anyaghasználat az épület egyik legfontosabb jellegzetessége.

_ Az OMM múzeum alapja a faépítészet. A fa térszervezésének, homlokzatának és szerkezeti rendszerének is alapvető eleme. A döntés nem véletlen: a faépítészetnek Törökországban régi hagyományai vannak nemcsak a vernakuláris építészetben, hanem középületeknél is. Az OMM tervezőire két fontos épülettípus is hatással volt. Az első az úgynevezett tüteklikli, amely egy Törökországban népszerủ fa tetőszerkezetet takar. A tipikus tüteklikli pontosan úgy épül, ahogyan az OMM homlokzata: a fagerendákat egymásra keresztbe fektetve réteges szerkezetet alakítanak ki. A tetőszerkezet felfelé keskenyedik és kéményszerủ 03 megnyitással zárul. Az OMM-ben ez az elem központi felülvilágítóval jelenik meg. A másik fontos történelmi előkép a törökországi mecsetek faépítészete. A régi famecsetekből több ma is működik. Kuma ezekre utalva nemcsak a hagyományokat hívja életre, hanem egyben egy napjainkban reneszánszát éló építőanyag kortárs használata 07 mellett is érvel.

_ A török hagyományokhoz igazodik az épület tervezése is, amely sokkal radikálisabb, mint Kuma korábbi épületei. A japán mester jellemzően az egyszerủ alaprajzi rendszerek híve, ami általában négyzetes tömegekben valósul meg. Ez az egyszerủ megoldás egyszerre hivatkozás a japán népi építészetre és a kortárs-modern építészetre. Ebből a letisztult formavilágból lép ki a Victoria \& Albert 

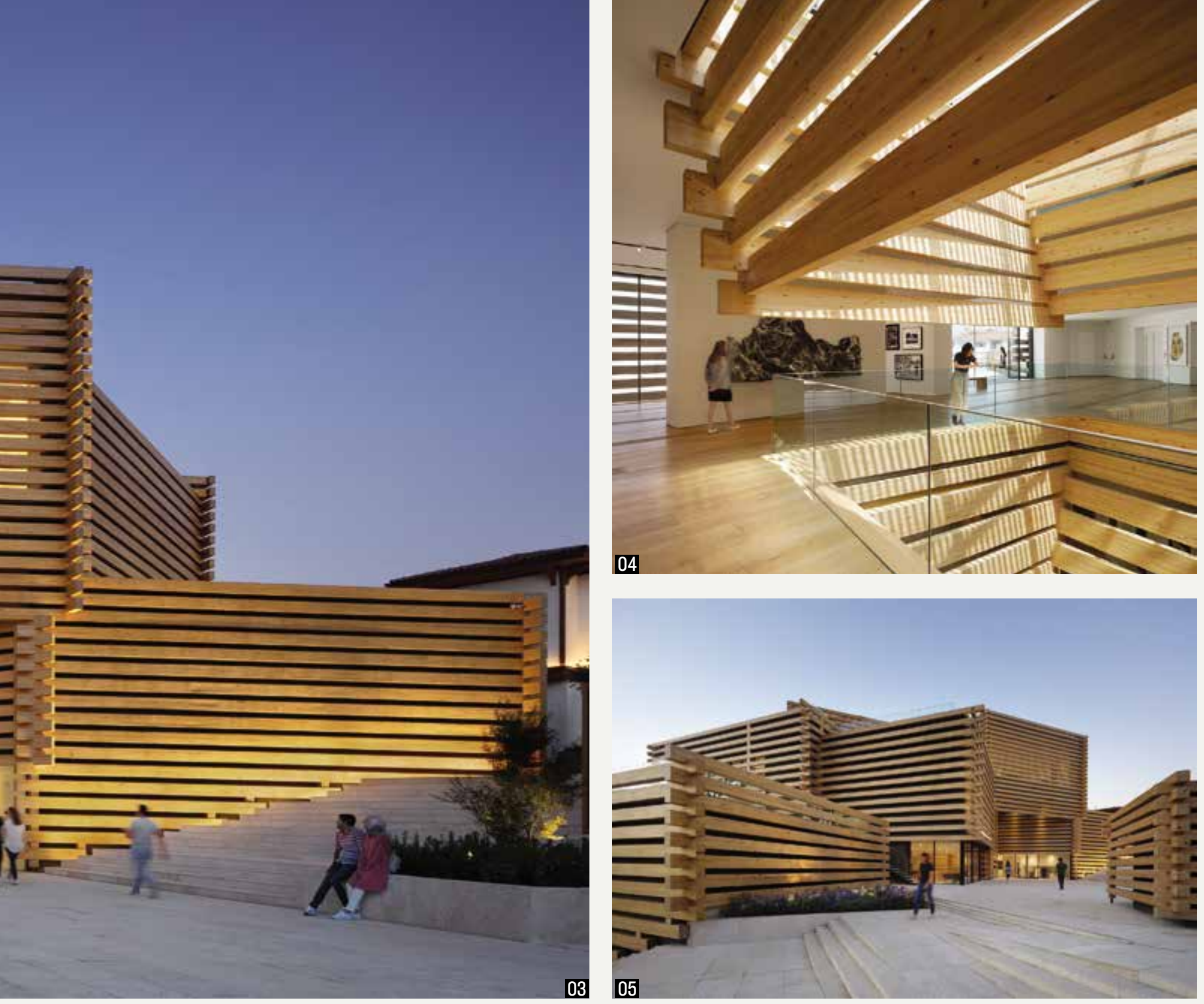

03 Főbejárat és lépcső a külső teraszra

04 Belső átrium: a faburkolat a belső hangulatot is uralja

05 Külső pláza: a város nemcsak egy impozáns épülettel, hanem egy kortárs városi térrel is gazdagodott

Múzeum, ahol az épület elforgatott tömegekkel dolgozik, egy részben fedett közteret hozva létre. Hasonló köszön vissza az OMM múzeum esetében is, ahol a térszervezést és az épület tömegét a hagyományos török geometrikus díszítések ihlették. Ezeket a komplex formákat egyszerü mủveletekkel (elforgatás és metszéspontok összekötése) hozzák létre. Egy minta tervezésénél fontos szempont, hogy a végső minta komplexitása nem az elemek bonyolultságából, hanem azok kapcsolatából jön létre. Ugyanez igaz az OMM esetén is, ahol az elemek ismétlésével és elforgatásával egy sajátos kapcsolatrendszer jön létre, ami a külső és belső térhatásban is visszaköszön.

__ A külső forma esetén nemcsak egy sajátos dinamikáról van szó: az egymásra helyezett tömegek konzolosságával 05 a múzeum a környező házakra is utal, amelyeknél az első emelet jellemzően nagyobb a földszintnél, és konzolosan épül. Ez az úgynevezett bagdadi háztípus egy faszerkezetes és tégla vázkitöltős építési módot takar. A múzeum külső formája tehát fontos utalás a környezetre és a hely történelmi kontextusára is, mivel az épület Eskişehir központjában áll, ami Anatólia fővárosa.

_ A külső dinamika a belső világban is visszaköszön: az épület nagy érdeme, hogy a faépítészet nemcsak a külső burkolatban, hanem a belső terekben is megjelenik. A dinamikus tömeg nagy előnye, hogy változatos kiállítási terek létrehozását teszi lehetővé, amelyek vizuális kapcsolatokban (átlátásokban), magasságban vagy alaprajzi méretben is sokféleséget mutatnak. A japán mester múzeuma egyszerre látványos építészeti alkotás, mégis képes a kiállításhoz mérten háttérben maradni. A látszólagos ellentmondás feloldására megoldást Kuma itt is a természetességben és a letisztult tervezési logika őszinteségében találja 

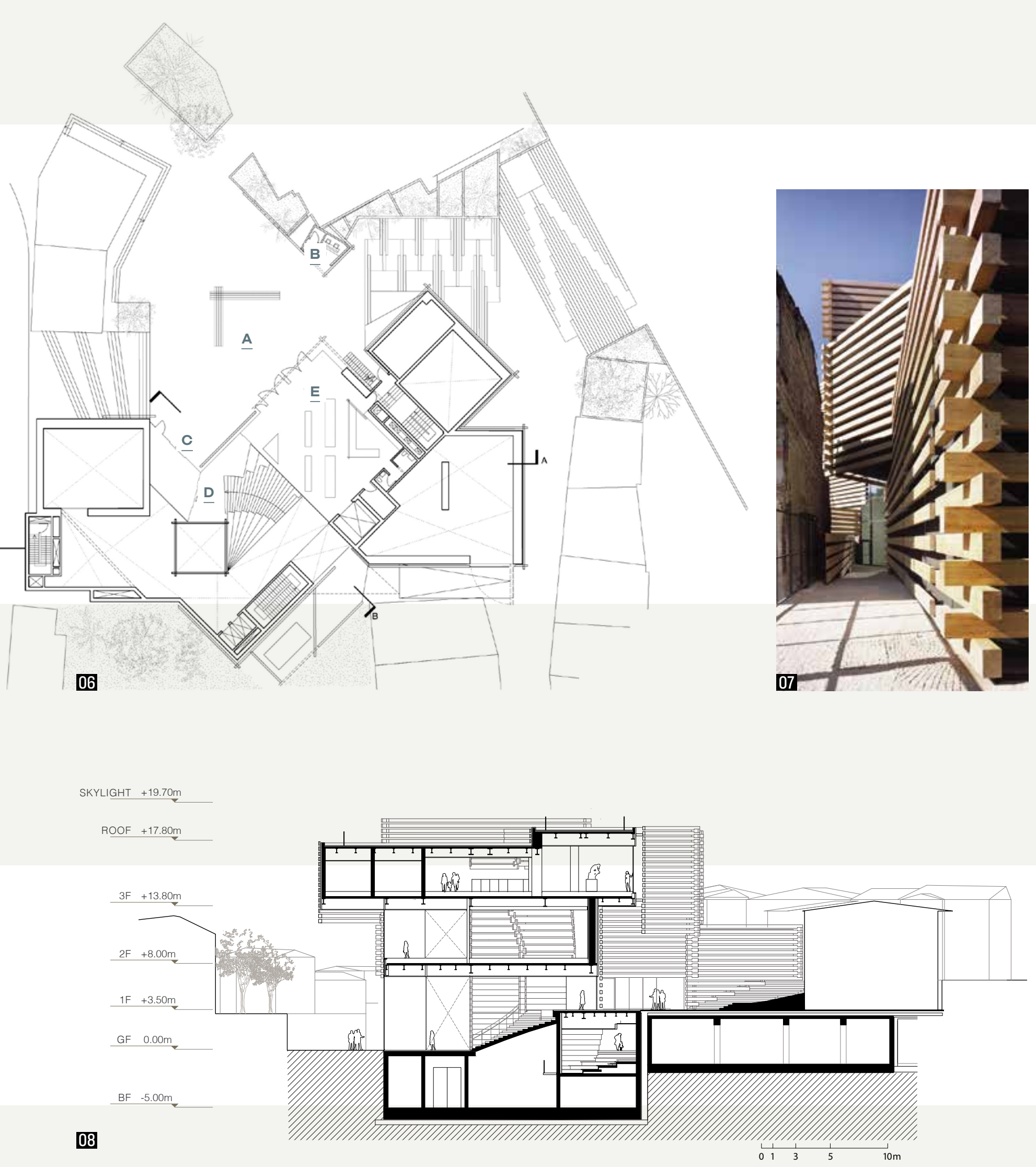

meg. Az épület egyszerủ elvet követ: a terek felfelé haladva egyre kisebbek, ami Erol Tabanca művészeti gyűjteményé- 08 nek igényeihez kiválóan igazodik. A nagyobb mủalkotások az alsó szinteken, a kisebb tárgyak a felső emeleteken nyertek elhelyezést. Az átlátásoknak egy másik előnye is megmutatkozik, hiszen a nagyobb tárgyakat több nézőpontból is megtekintheti a látogató. Kengo Kuma múzeuma minden ízében igazi mestermunka: térszervezésében, használatában, karakterében rendkívül sokrétủ épület, amely a hagyományos gyökerekből építkezik, de ezt a kortárs építészet mértékletességével, szigorával és sokrétegüségével teszi. 


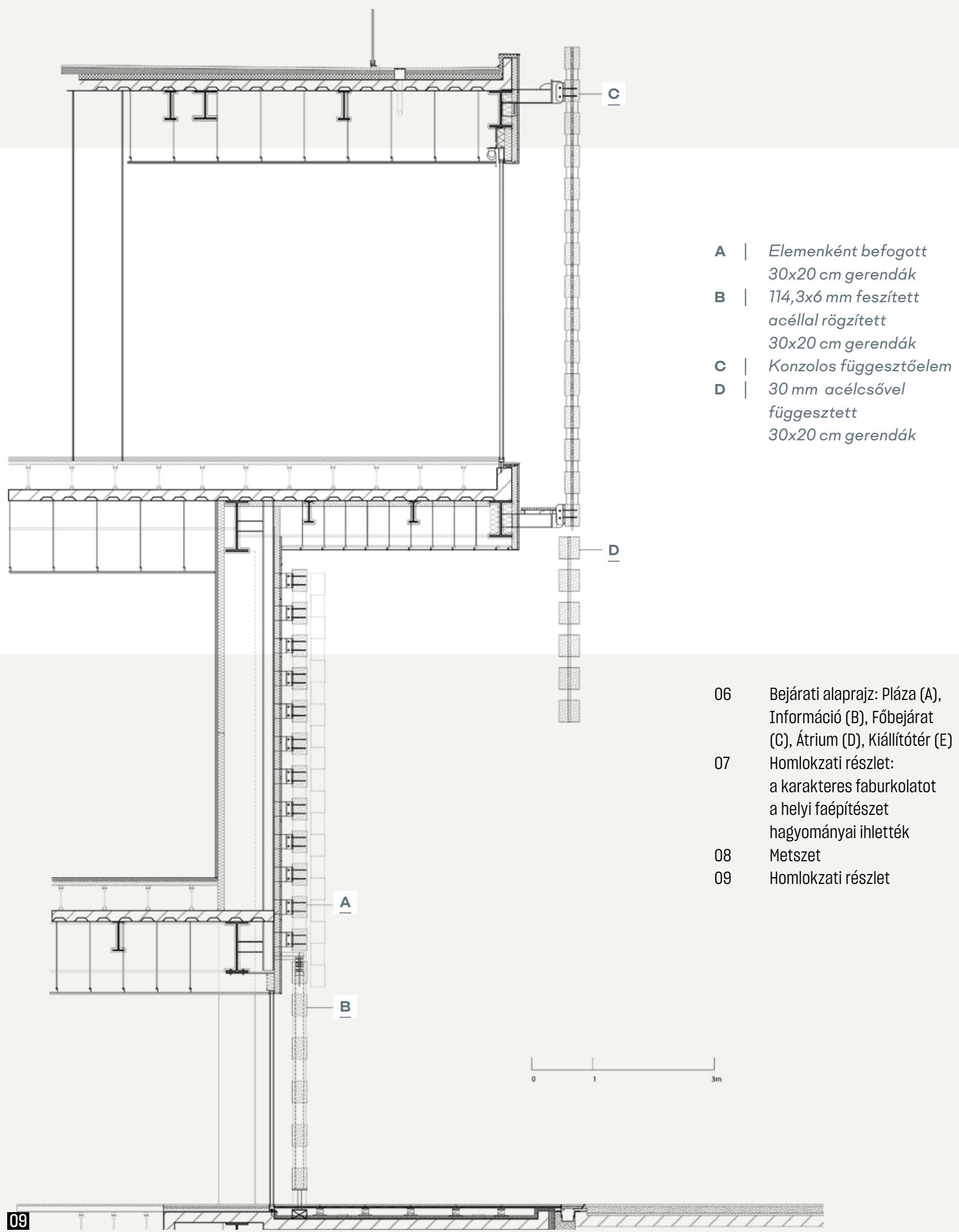

IRODALOM / REFERENCES

[1] Frampton, Kenneth: Kengo Kuma: Complete Works, Thames and Hudson, London 2013, pp 116-128.

[2] Bognár, Botond: Kengo Kuma: Selected works, Priceton Architectural Press, New York 2005, pp 80-88.

[3] Scaglione, Pino: Kengo Kuma: Architecture as Spirit of Nature, ListLab, Trento 2018, p 6.
ÉPÍTÉSZ: Kengo Kuma and Associates | ÉPÍTTETŐ: Polimeks Holdings, INC. I VEZETŐ TERVEZOO: Yuki Ikeguchi (Ikegucsi Juki) | MUNKATÁRSAK: Yasemin Sahiner (projektvezető), Man Wai Yiu (Jiu Men Vei), Anteo Taro Sanada (Szanada Anteo Taro), Jagoda Krawczyk, Akihiro Moriya (Morija Akihiro) I STATIKA: SIGMA | GÉPÉSZET: TEMA Engineering and Co 


\section{ABSTRACTS}

\section{WESSELÉNYI-GARAY, Andor: AFTER POST ORGANIC ARCHITECTURE \\ Citation: Metszet, Vol 11, No 4 (2020), pp 11-17, DOI: 10.33268/Met.2020.4.1 \\ FAMILY HOME, BUDAKESZI, HUNGARY | Architect: Gábor and Orsolya BÁRTFAI-SZABÓ}

The regional tradition for developing linear rural homes has been reinvented for this family home. Referencing past works of respected

Hungarian architects and the influence of studying under the Mesteriskola and
Vándoriskola programs guided this project's architect. The home is divided into clear functional elements, daytime, nighttime with transitional areas that are linked by a common veranda. This in theory follows the Hungarian rural tradition: to a point, after which the architectural language and use of materials follow a more contemporary vein.

\section{WARE-NAGY, Orsolya: COMMUNITY BUILDING}

Citation: Metszet, Vol 11, No 4 (2020), pp 18-23, DOI: 10.33268/Met.2020.4.2

SAINT PETER'S CATHEDRAL, WORMS, GERMANY | Artworks by: Anna HERINGER and Martin RAUCH

In this project to redesign of liturgical spaces in a cathedral the community came together with artists to create rammed earth furnishings: the pulpit, altar and prayer stands was put to the task to strengthen the rammed earth structures, meaning all materials were taken directly from nature. The link between nature and human activity being implemented that the so-called sophistication of western ideals does not really differ from out poorer counterparts elsewhere. Creativity is a proof of the brotherhood of man.

\section{GUTAI, Mátyás: TRADITION BALANCE}

Citation: Metszet, Vol 11, No 4 (2020), pp 24-29, DOI: 10.33268/Met.2020.4.3

\section{ODUNPAZARI MODERN MUSEUM, TURKEY | Architects: KENGO KUMA}

Kengo Kuma's museums always reinterpret local tradition, and his new work in Turkey, Odunpazari Modern Museum is another example of this design approach. Wooden architecture has great trradition in Turkey, so Kengo Kuma chose this material, which results in a playful appearance with horizontal wooden lamels and light filtering through. Not only the facades, but the floor plan was also influenced by vernacular architecture, hence the rotated building masses that also create new, contemporary public spaces.

\section{Citation: Metszet, Vol 11, No 4 (2020), pp 30-33, DOI: 10.33268/Met.2020.4.4} PRATA HOUSING COMPLEX, LISBON, PORTUGAL | Architects: RPBW, RENZO PIANO

Originally conceived just over twenty years ago the Prata Housing complex in Lisbon has finally moved ahead. Designed to be an energy aware redevelopment on a brown field, site where technical development of these residential units addresses issues of public and private spaces, orientation and azulejo a nod towards the regional use of azulaj tiles. The obvious similarity between locally produced ceramic tiles and the not intended decorative repetition of solar cells lead towards the development of a high tech azulej solar roof system, which generates energy, opens for means of ventilation and serves as a blue on white decorative motif.

\section{WETTSTEIN, Domonkos: STRUCTURAL DYNAMICS: ŐRMEZŐ CITY GATE}

Citation: Metszet, Vol 11, No 4 (2020), pp 34-39, DOI: 10.33268/Met.2020.4.5

BUDAPEST ONE OFFICE BUILDING, BUDAPEST, HUNGARY | Architects: Gergely PAULINYI, András REITH and István VÁMOSSY

Rust Belt redevelopment has led to the increase of flagship commercial building projects at key points along main arterial roads and railways into major cities.

Environmental impact and sustainability guided the design team towards an innovative use of generative design analysis which treats the building as a design object arrived at by the application of computable algorithms. The final result being a complex geometric form where controlled assessment of daylighting, ventilation and user patterns assisted in creating a free-flowing outer shell.

\section{BIHARI, Ádám - MEDGYASSZAY, Péter: PRESENT ADOBE CONSTRUCTION AND EXPECTED FUTURE TENDENCIES}

Citation: Metszet, Vol 11, No 4 (2020), pp 40-43, DOI: 10.33268/Met.2020.4.6

The construction industry faces many challenges over the next decade. Adobe or to be more accurate earth-based construction methods are limited when applied to traditional brick and wall finishes, yet with the advance of technology prefabricated or robotic solutions offer a viable way forward. Both traditional and future technologies will need to be regulated and monitored correctly considering financial, social and environmental impact. Once this is achieved embarking upon a path forwards can easily occur.

KONDOR, Tamás - JUHÁSZ Hajnalka: HUNGARIAN NEST

Citation: Metszet, Vol 11, No 4 (2020), pp 44-47, DOI: 10.33268/Met.2020.4.7

NEW TYPES OF ENERGY SPACES IN SUSTAINABLE ARCHITECTURE

Developing ideas explored in the Solar Decathlon competition the reality of exploring how to improve on the Hungarian cube-like house type with the hope of expanding upon the use of vernacular elements to create a low-cost passive housing typology. Here the external and intermediate spaces have been included in the generation of a successful microclimatic experiment. Zoning of a home from private to public has proven to hold environmental impact solutions for energy positive homes.

MATOLCSY, Károly - TERJÉK, Anita - ZAJÁROS, Anett: REMOURBAN: SMART CITIES AND COMMUNITIES

Citation: Metszet, Vol 11, No 4 (2020), pp 48-51, DOI: 10.33268/Met.2020.4.8 METHODS, RESULTS, GOOD PRACTICE AND LESSONS

The EU project, Regeneration Model for accelerating the smart URBAN transformation, consists of 22 partnerships across 7 member states. Three existing city projects: Nottingham, Tepebaşi and Valladolid have returned positive results, now the project will be further expanded to the cities of Seraing and Miskolc. To date projects have focused upon smart infrastructure from the point of view of energy consumption, in Miskolc this will be extent towards public utilities and urban public transport. 